\title{
Technical solutions for under-row weed control in vineyards: Efficacy, costs and environmental aspects analysis
}

\author{
Marco Manzone, Mattia Demeneghi, Paolo Marucco, Marco Grella, Paolo Balsari \\ Department of Agricultural, Forest, and Food Science, University of Turin, Grugliasco (TO), Italy
}

\begin{abstract}
Weed control in vineyards is essential to allow optimal vines development. In this study, three different techniques (hoeing, chemical control, and mulching) used in vineyard's under-row weed control were compared considering their: operative and economic aspects, energy consumptions and environmental impacts. Trials were performed in a vineyard located in Canelli (AT), Italy, characterized by 3 different gradient slopes $(<5 \%, 10-15 \%$, $>20 \%$ ). Each technique has been tested in 3 adjacent rows per each of the 3 vineyard slopes (randomized block test). Two weed control treatments were performed (at 50 days interval) during the peak vegetation growth period (from mid-April to mid-August). Major families of weeds in the test rows were described and scored (\%), and weed control efficiency was measured by comparing the weeds cover area projected to the ground vs the test area. Results highlights that the use of mulching machine and the boom sprayer permits to maintain a weed coverage lower than $30 \%$ independently of slope gradient. The hoeing, characterized by low operational costs $\left(26 € \mathrm{~h}^{-1}\right)$ and energy requirement $\left(550 \mathrm{MJ} \mathrm{ha}^{-1}\right)$, scored acceptable working performances, but, in case of heavy rains, it can cause a runoff of the soil. The chemical weed control, also if results a valid choice in term of work quality, is not a valid solution from the environmental point of view. The mulching machine, although shows higher operating costs compared to other machines tested $\left(30 € \mathrm{~h}^{-1}\right)$, can be considered as the most viable alternative to chemical weed control because its working efficiency is comparable to that obtained by the sprayer.
\end{abstract}

Correspondence: Marco Manzone, Department of Agricultural, Forest, and Food Science, University of Turin, Largo Braccini 2, 10095 Grugliasco (TO), Italy.

Tel.: +39.011.6708638.

E-mail: marco.manzone@unito.it

Key words: Weed control; vineyards; under-row; working rate; hourly cost; $\mathrm{CO}_{2}$ analysis.

Received for publication: 20 June 2019.

Accepted for publication: 2 November 2019.

CC Copyright: the Author(s), 2020

Licensee PAGEPress, Italy

Journal of Agricultural Engineering 2020; LI:991

doi:10.4081/jae.2020.991

This article is distributed under the terms of the Creative Commons Attribution Noncommercial License (by-nc 4.0) which permits any noncommercial use, distribution, and reproduction in any medium, provided the original author(s) and source are credited.

\section{Introduction}

In Europe vine cultivation is very spread, especially in Mediterranean area which is the location of three major European wine producers: Italy, France and Spain (OIV, 2018). Only in Italy about 700,000 hectares are dedicates to vineyards accounting for 6.9 million of tons of grapes produced (OIV, 2018).

In order to improve the quality and quantity of grapes production, vineyards require an accurate weed control. In fact, the weed incidence is considered one of the main causes of the grapes production reduction (Cirujeda et al., 2012). Generally, in vineyards it is possible to distinguish two different type of weed control: inter-row and under-row. The inter-row weed control can be carried out using conventional implements coming from the agricultural sector adapting their working width to inter-row distance. Differently, the under-row weed control must be performed using specific implements developed for this purpose able to remove weeds near the vine trees without damaging them (Tamagnone et al., 2011).

Independent of inter-row or under-row weed control techniques used, the techniques adopted are dependent on morphological area characteristics or vineyard training system. To date, the widespread weed control techniques are fundamentally three: i) chemical control by use of herbicide application; ii) mechanical control trough grass shredding; or iii) soil harrowing (Balsari et al., 2006). Herbicides use, even if it is cheaper compared to other techniques, causes some problems linked to environmental contamination and human health (Narayan et al., 2017). In the last years, to reduce the pollutant process due to plant protection products application during grow cycle of the vineyards, several direct and indirect measures were proposed. Among direct measures spray drift reducing technologies were proposed as effective to reduce spray drift at source (Grella et al., 2017; MirandaFuentes et al., 2018). Considering the weed control operations, the permanent grassing, soil covered with rock fragments, soil mulching using different plastic and organic materials, were proposed as the main alternatives to the chemical weed control in order to achieve a higher environmental sustainability. In fact, the choice of better weed control technique is based on various criteria like soil erosion, area slope, soil conservation, and environmental impact, not only the efficacy in weed control. Nevertheless, in order to reduce the cultivation costs increasing at the same time crop profitability, some farmers prefer to group different agricultural activities in one operation; the growers make the soil tillage combined with the weed control because it aerates the soil with consequent agronomic benefits.

The soil tillage can be made using different implements that generally are chosen considering the following parameters: soil working device, main technical characteristics (mass, power required, working width), working quality (weed control efficiency), soil main characteristics (geomorphology, type, rocks presence), and vineyard layout. A wrong implement choice may pro- 
duce environmental undesirable effects, such as increasing the soil erosion caused by runoff or wind (De Laune and Sij, 2012), increasing at the same time the grower cost due to tractor high power consumption. The objective of this experimental work was to compare three different vineyard under-row weed control methods, in order to identify the best management options balancing the operative and economic aspects, energy consumption and environmental impacts.

\section{Materials and methods}

The experimentation was carried out in the North-West of Italy at the farm 'Ghione Anna' in Canelli (AT) $\left(44^{\circ} 43^{\prime} 17.2^{\prime}\right.$ 'N; $\left.8^{\circ} 15^{\prime} 38.8^{\prime \prime} \mathrm{E}\right)$. Tests were performed in a vineyard of Barbera (Vitis vinifera 'Barbera') 15 years old with a layout of $2.5 \mathrm{~m} \times 1 \mathrm{~m}$, espalier trained and Guyot pruned. During the test, weeds showed a BBCH-scale of 25 with a height of about $20 \mathrm{~cm}$.

In the trials, three machines usually used for under-row weed control were employed: a tiller (B.F.M, B1, Cuneo, Italy) with axial hoeing head (tiller) (Figure 1), a short mounted boom sprayer (Abbà, Cuneo, Italy) equipped with a single nozzle XR11004VS (Teejet Technologies, IL, USA) for chemical control (sprayer) (Figure 2), and a mulching machine (Dragone, CR16, Asti, Italy) (mulcher) (Figure 3 and Table 1). All machines were set with a working width of 0.45 meters and they were attached to the threepoint hitch and powered by a crawler tractor, featured by a power of $40 \mathrm{~kW}$ and with a mass of $2680 \mathrm{~kg}$.

The performance of the different equipments was evaluated on sample areas corresponding to 15 -meter long row. Within each of these areas, delimited by two poles, there were 15 plants. All machines were set up to work on a strip of $0.6 \mathrm{~m}$ under the row ( 0.3 $\mathrm{m}$ on each side of the vine trees). All tests were performed using a forward speed of $3 \mathrm{~km} \mathrm{~h}^{-1}$ because this is the max forward speed allowed by using the crawler tractor in all working conditions.

During the test, the sprayer applied a volume of $3201 \mathrm{ha}^{-1}$ (at $0.15 \mathrm{MPa}$ pressure) referred to the real sprayed area (this volume correspond to about $75 \mathrm{l} \mathrm{ha}^{-1}$ referred to vineyard surface) using glyphosate at a dosage of $0.81 \mathrm{ha}^{-1}$ of active ingredient.

The tests were performed in three areas characterized by different gradient slopes: i) less than $3 \%$, indicated as Slope A; ii) between $10-15 \%$ indicated as Slope B; iii) more than $20 \%$ indicated as Slope C. In each vineyard slope area the three machines were tested in three adjacent rows (randomized block test); a portion of each row was left untreated (weeds infested) as control sample (Figure 4). Irrespective of slope, all land plots used for the trials showed similar physical soil characteristics: clay soil with a moisture content from 10 to $12 \%$. Each plot had a length of 20 metres. For each machine, working times and manpower requirement were recorded on the field, according to CIOSTA (Comité International d'Organisation Scientificue du Travail en Agricolture) methodology (Manzone and Balsari, 2014). Working rate was estimated using analytic method that considers the worked surface in the unit time and it was expressed as ha $\mathrm{h}^{-1}$.

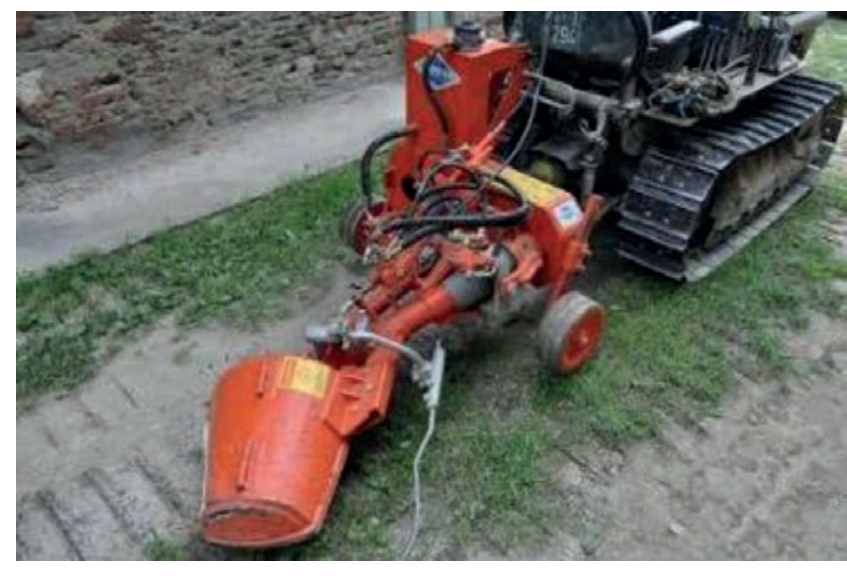

Figure 1. Under-row tiller with axial hoeing head.

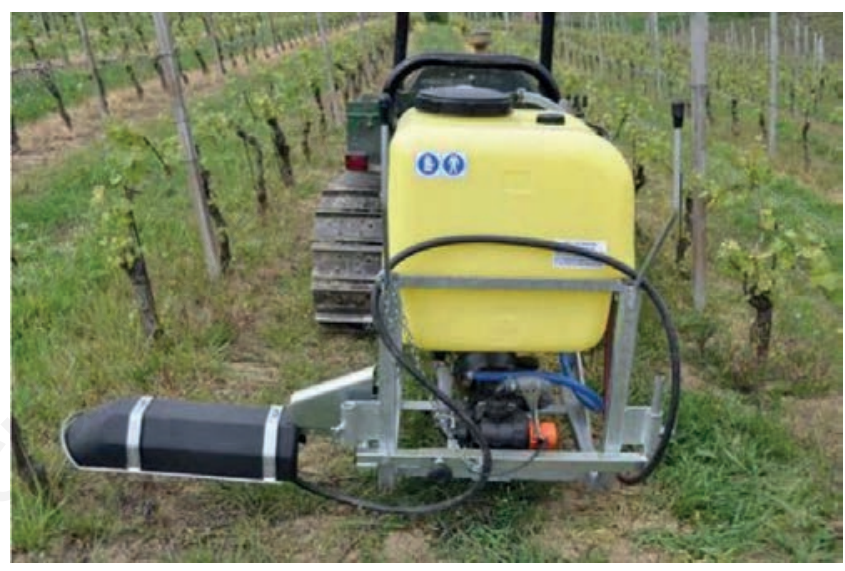

Figure 2. The boom sprayer chose for the trials.

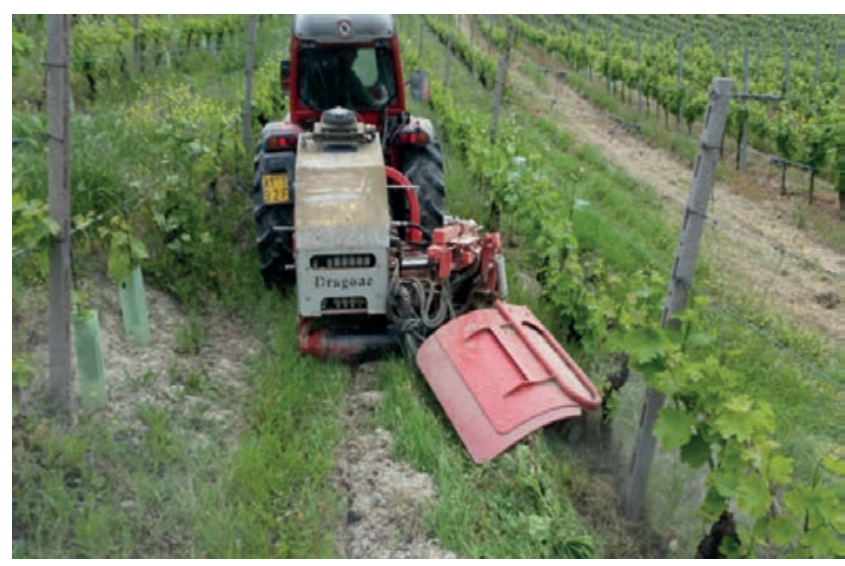

Figure 3. Mulcher machine used in the test.

Table 1. Main technical characteristics and price of the machines used in the trials.

\begin{tabular}{|c|c|c|c|c|c|}
\hline Technique & Machine type & Mass (kg) & Power required (kW) & Working type & Price $(€)$ \\
\hline Hoeing & Rotary tiller & 240 & 4.8 & Hoeing & 6120 \\
\hline Chemical control & Sprayer & 62 & 1.7 & Herbicide distribution & 1200 \\
\hline Mulching & Mulcher & 420 & 12.0 & Weed mulching & 5900 \\
\hline
\end{tabular}


The required manpower was determined considering the minimum number of operators necessary to the machine and the working time spent per unit surface (ha).

Working quality of each machine tested was determined evaluating the weed control in two different tests performed (at 50 days interval) during the peak vegetation growth period (from midApril to mid-August, 2016). Families of weeds present in the test rows were described and scored (\%), and weed control efficiency was measured by comparing coverage of control parcels (untreated) vs the test area $(0.8 \times 0.6 \mathrm{~m})$. Every 10 days, in each test row, weeds were visually assessed and scored, always by the same operator throughout the study period. The efficacy of weed control was expressed as $\%$ of weeds removed after each treatment, and weeds re-growth was analyzed over the time. Since the weather conditions show a high influence on the weed growth, a weather station Vantage Pro2 GoWeather (Davis Instruments Corporation, CA, USA) was placed near the area used for tests monitoring the air temperature $\left(\mathrm{C}^{\circ}\right)$, air relative humidity $(\%)$ and rainfall $(\mathrm{mm})$.

In this experiment, the total energy required for each machine was determined by considering the direct energy consumption - the energy input to perform the weed control operation (tractor fuel and lubricant consumption) - and the indirect energy consumption - the energy used for the tractor and implements manufacturing (Manzone, 2016). An energy content of $92.0 \mathrm{MJ} \mathrm{kg}^{-1}$ for the tractor and an average value of 69.0 MJ for each kilogram of mass was considered for all of the implements (Mikkola and Ahokas, 2010). The direct energy input was calculated considering an energy content of $37.0 \mathrm{MJ} \mathrm{L}^{-1}$ for the diesel and of $83.7 \mathrm{MJ} \mathrm{kg}^{-1}$ for the lubricant. Additionally, $1.2 \mathrm{MJ} \mathrm{kg}^{-1}$ was added to these values, as energy required in their transportation and distribution.

The fuel consumption for the weed control operation was determined by the topping-off system (Manzone, 2015a). This method involves measuring the fuel consumption before and after to have worked a specific surface. The forward speed was determined using two couples of photocells ZOOM Z2E (Nologo S.r.l., $\mathrm{Mi}$, Italy) placed at the distances of $10 \mathrm{~m}$. In order to reduce the eventual effect of the lower forward speed during the manoeuvres in headland on the effective operative forward speed, the photocells were positioned at a distance from headland boundaries of at least $5 \mathrm{~m}$. All distances were measured by a flexible metric ruler (Super active) (Metrica Spa, Mi, Italy) with accuracy of $2 \mathrm{~mm}$. In each testing area $\left(2000 \mathrm{~m}^{2}\right)$, the forward speed was determined with three replications. Since lubricant consumptions are very low in the unit time spent for test, these were estimated as a function of diesel consumptions according to the ASAE standards (1999).

The environmental impact of the weed control in vineyards was determined through $\mathrm{CO}_{2}$ emission analysis. The analysis was carried out considering the $\mathrm{CO}_{2}$ emissions from fuel combustion, lubricant consumed and machines maintenance and repair. Moreover, only for the sprayer, also the $\mathrm{CO}_{2}$ emission in herbicide production were considered. This parameter was expressed in terms of $\mathrm{kg}$ of $\mathrm{CO}_{2}$ emitted per unit surface worked (ha).

In this study, $2.94 \mathrm{~kg}$ of $\mathrm{CO}_{2}$ for each $\mathrm{kg}$ of lubricant and 3.76 $\mathrm{kg}$ of $\mathrm{CO}_{2}$ per litre of fuel emitted into the environment were considered. A value of $0.16 \mathrm{~kg} \mathrm{CO}_{2}$ released into the atmosphere per each MJ of energy content in the machines was assumed for maintenance and repair (Manzone, 2015a). Furthermore, an amount of $6.30 \mathrm{~kg} \mathrm{CO} 2$ per each litre of herbicide was considered in the calculation (Khoshnevisan et al., 2013).

The procedure used to calculate the machine cost was described by Miyata (1980), considering an annual utilisation of $500 \mathrm{~h}$ for the tractor (tractor used also for other operations) and 200 $\mathrm{h}$ for all implements tested. The investment costs used in the calculation for implements were reported in the Table 1, while the tractor ones amounted to $22.30 €$. The depreciation period was assumed to be six years for implements and ten years for the tractor. Value retention at the end of this period was assumed to $20 \%$ of the initial investment. Repair and maintenance costs were considered those incurred directly by the machine owner (average value obtained during 5 years). Labour cost was considered to be $18.50 € \mathrm{~h}^{-1}$ (Manzone, 2015b). A value of $1.10 € \mathrm{dm}^{-3}$ and $5.50 €$ $\mathrm{kg}^{-1}$ were assumed for fuel and lubricant, respectively.

All statistical analyses were performed using IBM SPSS Statistics (Statistical Package for the Social Sciences) for Windows. Separate ANOVA models considering slope gradient as a fixed effect for each weed families and weed families as a fixed effect for each slope gradient were made. Moreover, ANOVA models were used for all other parameters considered: Working rate, manpower, and energy consumption. Eventual differences between tests were checked by performing Tukey's multiple comparison test, adopting a significance level of $\alpha=0.05$. Tukey's test was used because it highlighted a high power with this data distribution.
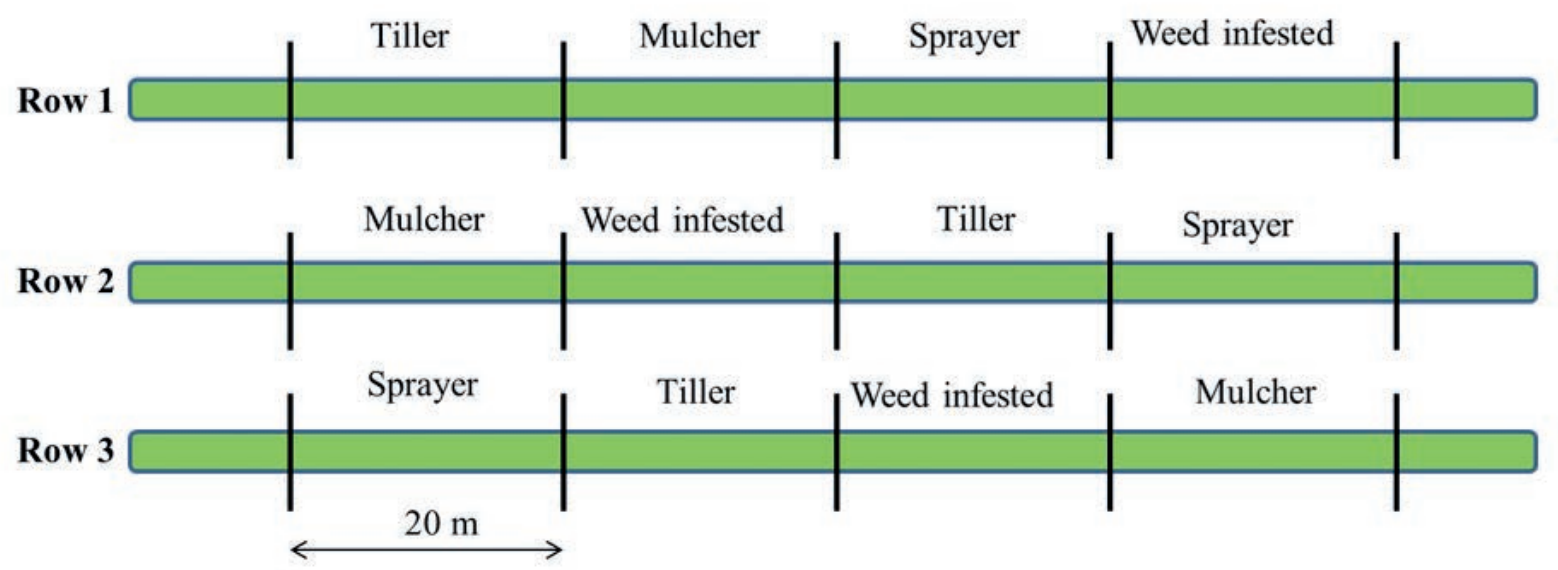

Figure 4. Plots disposition. 


\section{Results}

\section{Weather conditions}

Air temperature during the test period ranged between 3 and $27^{\circ} \mathrm{C}$ (daily average of $17^{\circ} \mathrm{C}$ ), while the monthly average air humidity varied between $64 \%$ and $72 \%$. During the experimental period (50 days before the first treatment and 50 days after the second treatment), $158 \mathrm{~mm}$ of rain were measured. Each rain event contributed up to $22 \mathrm{~mm}$ and these were mainly concentrated between the first and the second treatment (Figure 5). All values of these parameters were in line with those recorded by the same weather station in the last five years. In this period, in fact, the daily average air temperature was $18^{\circ} \mathrm{C}$, the monthly average air humidity varied between $60 \%$ and $74 \%$ and the average amount of water precipitations was $143 \mathrm{~mm}$.

\section{Weed analysis}

Weeds present in the tested area was a mix of different species belonging to different botanic families, among them two were the predominant: Poaceae about $65 \%$ and Asteraceae about $25 \%$. Two way ANOVA showed no difference between the botanic families composing the weed coverage in all plots sited in the three different vineyards slope gradients (Table 2).

\section{Working times}

During the trials all machines have guaranteed a good level of work efficiency showing a high productive working time (94\%). No difference in splitting working time were highlighted. Unproductive time, mainly due to workers' break, were limited (1\%) for all implements and the 5\% remaining was attributable to time required in headland for maneuvers.

The higher working rate was obtained by sprayer and rotary tiller with values of about 0.41 ha per working hour. Statistical analysis showed no difference between different slope gradient for all tested machines (Table 3 ).

Similar values trend was found regarding the manpower requirements; the better performance was obtained by sprayer and rotary tiller $\left(2.49 \mathrm{~h} \mathrm{ha}^{-1}\right)$. Also this parameter resulted not influenced by the slope gradient (Table 3 ).

\section{Working quality}

Data processing highlighted that after the second treatment the weed growth was lower (about 30\%) compared to the first treatment (Table 4). The difference could be attributable to different weather conditions, in fact, the second treatment was performed in summer where the climate was dry while the first treatment was carried out in spring when the rain events were more frequent. The statistical analysis showed significant difference between all machines tested, slope gradients, and treatments (Table 5).

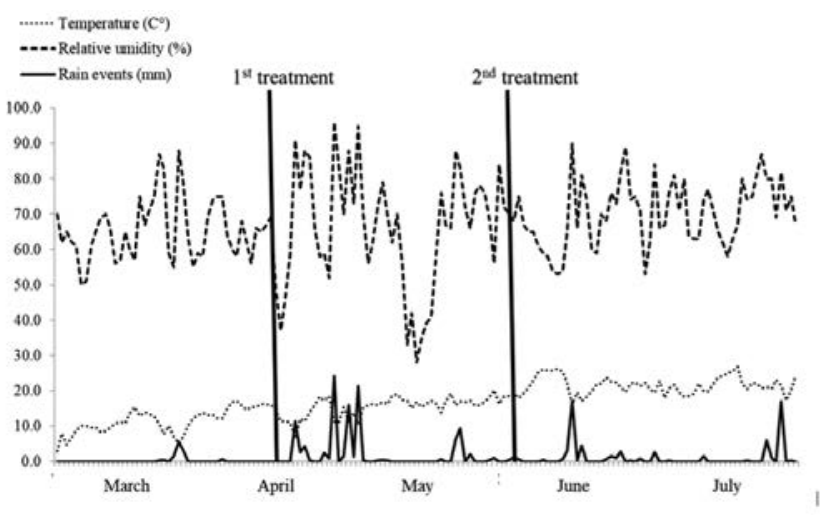

Figure 5. Weather data recorded during the experiment.

Table 2. Coverage percentage of different weed families in the different vineyard slope gradient $(A<5 \%, B=10-15 \%, C>20 \%)$.

\begin{tabular}{|c|c|c|c|c|c|c|}
\hline \multirow{3}{*}{$\begin{array}{l}\text { Weed } \\
\text { families }\end{array}$} & \multicolumn{6}{|c|}{ Slope gradient } \\
\hline & \multicolumn{2}{|c|}{ A } & \multicolumn{2}{|c|}{ B } & \multicolumn{2}{|c|}{ C } \\
\hline & Mean & SD & Mean & SD & Mean & SD \\
\hline Poaceae & $64^{\mathrm{aA}}$ & 2.44 & $62^{\mathrm{aA}}$ & 2.06 & $66^{\mathrm{aA}}$ & 1.91 \\
\hline Asteraceae & $24^{\mathrm{bA}}$ & 1.29 & $27^{\mathrm{bA}}$ & 1.29 & $22^{\mathrm{bA}}$ & 1.29 \\
\hline thers & $12^{\mathrm{cA}}$ & 0.57 & $11^{\mathrm{cA}}$ & 0.81 & $12^{\mathrm{cA}}$ & 1.41 \\
\hline
\end{tabular}

Slope: $\mathrm{F}=0.103 ; \mathrm{df}=2,35 ; \mathrm{P}=0.903$; weed families: $\mathrm{F}=3700.985 ; \mathrm{df}=2,35 ; \mathrm{P}<0.0001$; Slope $\times$ weed families: $\mathrm{F}=7529 ; \mathrm{df}=4,35 ; \mathrm{P}<0.0001)$. SD, standard deviation; values in table is a mean of 3 test replications; lower case letters indicate significant differences between percentage of different coverage families weed for each slope gradient separately; upper case letters indicate the statistical difference among slope gradients.

Table 3. Working rate and manpower of the tested machines as a function of gradient slope.

\begin{tabular}{|c|c|c|c|c|c|c|}
\hline & & & ope gr & ient & & \\
\hline $\begin{array}{l}\text { Working } \\
\text { rate }\end{array}$ & Mean & A & & DMean & $S$ & \\
\hline Hoeing & $0.40^{\mathrm{bA}}$ & 0.0048 & $0.39^{\mathrm{bA}}$ & 0.0100 & $0.39^{\mathrm{bA}}$ & 0.0076 \\
\hline Chemical control & $0.41^{\mathrm{bA}}$ & 0.0061 & $0.39 \mathrm{bA}$ & 0.0055 & $0.40^{\mathrm{bA}}$ & 0.0053 \\
\hline Mulching & $0.35^{\mathrm{aA}}$ & 0.0072 & $0.33^{\mathrm{aA}}$ & 0.0091 & $0.33^{\mathrm{aA}}$ & 0.0100 \\
\hline Manpower & Mean & A & $\begin{array}{l}\text { ope gr } \\
\text { Mean }\end{array}$ & $\begin{array}{l}\text { ient } \\
\text { SD }\end{array}$ & Mean & SD \\
\hline Hoeing & $2.49^{\mathrm{aA}}$ & 0.035 & $2.55^{\mathrm{aA}}$ & 0.031 & $2.51^{\mathrm{aA}}$ & 0.028 \\
\hline Chemical control & $2.43^{\mathrm{aA}}$ & 0.062 & $2.58^{\mathrm{aA}}$ & 0.075 & $2.44^{\mathrm{aA}}$ & 0.083 \\
\hline Mulching & $2.84^{\mathrm{bA}}$ & 0.085 & $3.03^{\mathrm{bA}}$ & 0.061 & $2.89^{\mathrm{bA}}$ & 0.076 \\
\hline
\end{tabular}

Working rate: Slope: $\mathrm{F}=9.332 ; \mathrm{df}=2,26 ; \mathrm{P}<0.0001$; machines: $\mathrm{F}=288.222 ; \mathrm{df}=2,26 ; \mathrm{P}<0.0001 ;$ Slope $\times$ machines: $\mathrm{F}=3.454 ; \mathrm{df}=4,26 ; \mathrm{P}<0.0001$. Manpower. Slope: $\mathrm{F}=12.432 ; \mathrm{df}=2,26 ; \mathrm{P}<0.0001$; machines: $\mathrm{F}=372.792 ; \mathrm{df}=2,26 ; \mathrm{P}<0.0001 ;$ Slope $\times$ machines: $\mathrm{F}=5.701 ; \mathrm{df}=4,26 ; \mathrm{P}<0.0001$. SD, standard deviation; values in table is a mean of 3 test replications; lower case letters indicate significant differences between machine type for each slope gradient separately; upper case letters indicate the statistical difference among slope gradients.

Table 4. Weed coverage after 50 days from the first and the second treatment.

\begin{tabular}{|c|c|c|c|c|c|c|c|c|c|c|c|c|}
\hline \multirow{3}{*}{ Slope gradient } & \multicolumn{6}{|c|}{ Treatment 1} & \multicolumn{6}{|c|}{ Treatment 2} \\
\hline & & & & & & & & & & & & \\
\hline & Mean & SD & Mean & SD & Mean & SD & Mean & SD & Mean & SD & Mean & SD \\
\hline Hoeing & 41.7 & 22.5 & 61.7 & 37.5 & 51.7 & 23.6 & 28.3 & 10.4 & 20.0 & 13.2 & 13.3 & 2.9 \\
\hline Chemical control & 16.7 & 20.2 & 3.3 & 2.9 & 5.3 & 5.0 & 13.3 & 23.1 & 5.9 & 5.8 & 0.0 & 0.0 \\
\hline Mulching & 23.3 & 14.4 & 13.3 & 2.9 & 10.0 & 2.9 & 28.3 & 23.1 & 6.7 & 5.8 & 8.3 & 2.9 \\
\hline
\end{tabular}

$\mathrm{SD}$, standard deviation; values in table is a mean of 3 test replications and they are a percentage value of the initial weed coverage relative to each treatment. 
In general, all machines have guaranteed a good work quality with an initial weed control higher than $95 \%$. Nevertheless, the chemical control needs a period of 10 days after the spray application to achieve the maximum efficiency (Figure 6). Differently from other machines tested, the rotary tiller showed a remarkable efficiency reduction on the weed control after 30 days from the treatment; in fact, the working efficiency resulted only $56 \%$ after 40 days and it reduced to $38 \%$ at the $50^{\text {th }}$ days from the first treatment (Figure 6).

\section{Energetic evaluation}

The energy consumption of the tested implements ranged between 469.2 and $848.3 \mathrm{MJ} \mathrm{ha}^{-1}$ as a function of the differences in their mass, fuel consumption and field capacity. The sprayer showed the lowest value (469.2 $\left.\mathrm{MJ} \mathrm{ha}^{-1}\right)$, while the rotary tiller showed the highest value $\left(588.7 \mathrm{MJ} \mathrm{ha}^{-1}\right)$. The incidence of the indirect energy always resulted lower than $1 \%$ of the total energy required to perform the weed control operation (Table 6).

\section{$\mathrm{CO}_{2}$ emission analysis}

The amount of $\mathrm{CO}_{2}$ eq emitted during the weed control ranged between $49.70 \mathrm{~kg} \mathrm{ha}^{-1}$ and $57.40 \mathrm{~kg} \mathrm{ha}^{-1}$. The higher value $(57.40$ $\mathrm{kg} \mathrm{ha}^{-1}$ ) was obtained by the rotary tiller, instead the lower value was observed with the mulcher use: fuel consumptions showed the mainly incidence $(98 \%)$ on the total $\mathrm{CO}_{2}$ emissions in both machines. On the other hand, although the sprayer has recorded a low value of $\mathrm{CO}_{2}$ emissions on fuel consumptions, intermediate value was highlighted $\left(50.86 \mathrm{~kg} \mathrm{ha}^{-1}\right)$ due to $\mathrm{CO}_{2}$ emission related to herbicide used $\left(5.10 \mathrm{~kg} \mathrm{ha}^{-1}\right)$. Lubricant consumption and maintenance and repair showed an incidence on total emissions always under $1 \%$ for all machines tested (Table 7 ).

Table 5. ANOVA results referred to weed coverage.

\begin{tabular}{lcccc} 
& SS & df & F value & P value \\
Correct model & $15,029.213$ & 17 & 88.706 & $<0.001$ \\
Intercept & $20,542.471$ & 1 & 2061.18 & $<0.001$ \\
\hline Treatment & 1768.51 & 1 & 177.448 & $<0.001$ \\
Slope & 1018.175 & 2 & 51.081 & $<0.001$ \\
\hline Technique & 7966.765 & 2 & 399.683 & $<.001$ \\
Treatment $\times$ Slope & 381.722 & 2 & 19.151 & $<0.001$ \\
\hline Treatment $\times$ technique & 2618.427 & 2 & 131.363 & $<0.001$ \\
Slope $\times$ technique & 784.324 & 4 & 19.674 & $<0.001$ \\
\hline Treatment $\times$ Slope $\times$ technique & 491.291 & 4 & 12.324 & $<0.001$ \\
Error & 358.789 & 36 & & \\
\hline Total correct & $15,388.002$ & 53 & & \\
\hline
\end{tabular}

SS, sum of squares; df, degree of freedom.

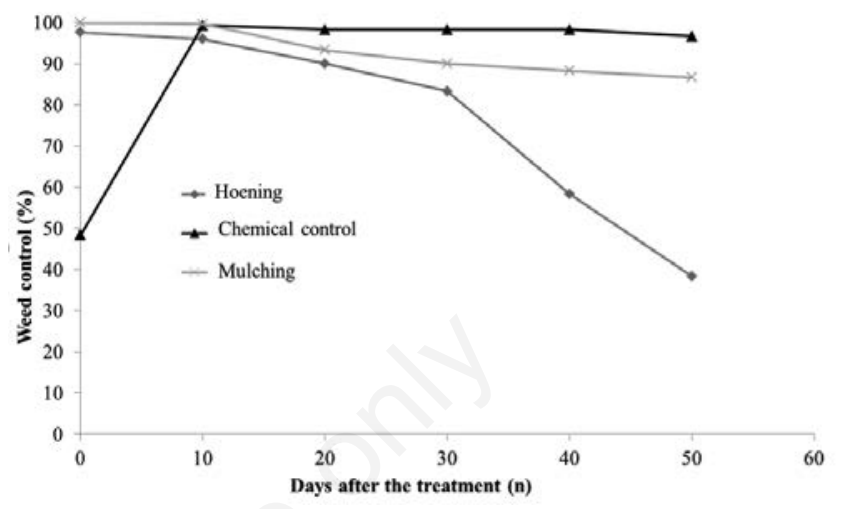

Figure 6. Weed control efficiency of the machines tested.

Table 6. Energy consumption (MJ ha ${ }^{-1}$ ) and hourly costs of the tested machines.

\begin{tabular}{|c|c|c|c|c|c|}
\hline Machine type & Direct energy & Indirect energy & Total energy & Hourly cost $\left(€ \mathrm{~h}^{-1}\right)$ & Cost for unit surface $\left(€ h^{-1}\right)$ \\
\hline Hoeing & 585.4 & 3.3 & 588.7 & 26.89 & 68.29 \\
\hline Chemical control & 466.5 & 2.7 & 469.2 & 32.41 & 80.52 \\
\hline Mulching & 506.4 & 3.1 & 509.5 & 29.38 & 86.09 \\
\hline
\end{tabular}

Table 7. $\mathrm{CO}_{2}$ emitted during the weed control.

\begin{tabular}{|c|c|c|c|c|c|}
\hline & \multicolumn{5}{|c|}{$\mathrm{CO}_{2}$ emitted $\left(\mathrm{kg} \mathrm{ha}^{-1}\right)$} \\
\hline & Fuel & Lubricant & Repair & Material & Total \\
\hline Hoeing & 56.47 & 0.41 & 0.52 & & 57.40 \\
\hline Chemical control & 45.00 & 0.33 & 0.43 & 5.10 & 50.86 \\
\hline Mulching & 48.85 & 0.36 & 0.49 & & 49.70 \\
\hline
\end{tabular}




\section{Economic evaluation}

The economic analysis showed that the weed control cost ranged from 68.29 to 86.09 Euro per hectare. Lower values were achieved by rotary tiller, instead the highest value was observed for mulcher. Middle value $\left(80.52 € \mathrm{ha}^{-1}\right)$ was obtained by sprayer used for herbicide application (Table 6). The low value achieved by the rotary tiller can be attributed to the low power required and the non-use of additional material like plastic wire (mulcher) and chemical products (Sprayer).

\section{Discussion and conclusions}

The data collected would provide a set of useful information to be used in the selection of machine for under-row weed control in slope vineyards. Results showed that the slope gradient influences the weed regrowth independently of the machine types tested. Data suggests that weeds regrowth was limited on areas with a higher slope gradient. This result is not affected only by machines performances, but it could be related also to the lower water availability in the slope soil. The rainfall events in slope area generate the soil erosion but also limit the water penetration into the soil (Luo et al., 2018).

The use of mulchers and sprayers (chemical control) have allowed to maintain a weed coverage lower than $30 \%$ independently from the slope gradient. This weed coverage value could be considered the limit over which the weeds must be removed. Although this value can be considered as a fairly low threshold index, it must be considered that the rotary tiller cannot guarantee a weed coverage below $60 \%$.

In order to select the most suitable machine it is needed to consider also other parameters (energy required, economic cost, and environmental impact).

Although the rotary tiller used guaranteed an acceptable weed control during the tests, maintaining at the same time low hourly costs (about $26 € \mathrm{~h}^{-1}$ ) and energy requirement (550 $\mathrm{MJ} \mathrm{ha}^{-1}$ ), it can generate runoff in case of heavy rains (De Laune and $\mathrm{Sij}, 2012$ ). Nevertheless, this machine type is preferred to other weed control systems because with a single pass it is possible to perform more operations in simultaneous: weed control, soil aeration, and organic matter burying. In addition, fragmentation of the underground storage organs (e.g., thickened roots or rhizomes) of perennial species is an important aspect of the mechanical weed control (Ringselle et al., 2018). In fact, in these weed species, the clonal integration is beneficial to the clonal network as a whole thanks to its resources and information content (Lopp and Sammul, 2016). Fragmenting the storage organs can decrease their intraspecific competitions because dividing the resources of the underground network, it is possible to reduce the amount available to each fragment. Moreover, the plant parts damaged are more susceptible to infections (Imathiu et al., 2009).

The chemical weed control through the use of boom sprayer was the best choice in terms of work quality, but it is not the best environmental choice. The toxic effects of herbicide applied (glyphosate), especially if combined to heavy metals, can be persistent in soil until 120 days from the application (Domine et al., 1993). In general, herbicides are toxic not only to humans, but they are very dangerous for terrestrial organisms and microorganisms, plants and earthworms (Uwizeyimana et al., 2017). In the last years, chemical substances have contaminated also urban and suburban surface water around the world: in America (Smith, 2013), in Vietnam (Chau et al., 2015) and in China (Kong et al., 2015). In addition, the overuse of chemical products for weed control can select herbicides-resistant weeds; globally 208 resistant weed species have been individuated (Heap, 2013).

The mulcher, although showing higher operating costs compared to other machines tested mainly due to high power required $\left(30 € \mathrm{~h}^{-1}\right)$, can be considered as the most viable alternative because its working efficiency is comparable to that obtained by the sprayer. In addition, weed mulched and left at the soil surface can provide several advantages to the vineyard in terms of: reduction of surface runoff and soil erosion regulation of the soil surface temperature, capture of rainfall water, reduction of the water evaporation from the soil surface translated in soil water content increase, weeds control, and increasing of the total organic matter in the top soil (Castellanos-Navarrete et al., 2012).

From the environmental side impact, limited to $\mathrm{CO}_{2}$ emissions released in atmosphere, the under-row weed control showed values (49.70 $\mathrm{kg} \mathrm{ha}^{-1}-57.40 \mathrm{~kg} \mathrm{ha}^{-1}$ ) in line with those obtained during other agricultural activities: e.g. tree planting $\left(31 \mathrm{~kg} \mathrm{ha}^{-1}-92 \mathrm{~kg}\right.$ $\mathrm{ha}^{-1}$ ) (Manzone, 2016).

Although the mulcher highlighted higher $\mathrm{CO}_{2}$ emissions due to fuel consumptions, compared to the boom sprayer weed control system, it achieved the best environmental results because does not require the use of chemical compounds.

In conclusion, the mulcher can be considered the best environmental friendly alternative to chemical under-row weed control in vineyard, for its good performances in weed control despite high operative costs and energy requirement.

\section{References}

ASAE (American Society of Agricultural Engineers). 1999. ASAE Standards: Agricultural Machinery Management. EP466.2.

Balsari P., Marucco P., Vidotto F., Tesio F. 2006. Assessment of different techniques for weed control in vineyard. pp 529-534 in Proceedings of Giornate Fitopatologiche 2006, 27-29 March, Riccione (RN), Italy [in Italian].

Castellanos-Navarrete A., Rodriguez-Aragones C., De Goede R.G.M., Kooistra M.J., Sayre K.D., Brussaard L., Pulleman M.M. 2012. Earthworm activity and soil structural changes under conservation agriculture in central Mexico. Soil. Tillage. Res. 123:61-70.

Chau H.T.C., Kadokami K., Duong H.T., Kong L., Nguyen T.T., Nguyen T.Q., Ito Y. 2015. Occurrence of 1153 organic micropollutants in the aquatic environment of Vietnam. Environ. Sci. Pollut. Res. 1-10.

Cirujeda A., Aibar J., Anzalone A., Martin-Closas L., Meco R., Moreno M.M., Pardo A., Pelacho A.M., Rojo F., Royo-Esnal A., Suso M.L., Zaragoza C. 2012. Biodegradable mulch instead of polyethylene for weed control of processing tomato production. Agron. Sustain. Develop. 32:889-97.

Domine D., Devillers J., Chastrette M., Karcher W. 1993. Estimating pesticide field half-lives from a back-propagation neural network. SAR QSAR Environ. Res. 1:211-9.

Grella M., Marucco P., Manzone M., Balsari P. 2017. Effect of sprayer settings on spray drift during pesticide application in poplar plantations (Populus spp.). Sci. Total Environ. 578:42739.

Imathiu S.M., Ray R.V., Back M., Hare M.C., Edwards S.G. 2009. Fusarium langsethiae pathogenicity and aggressiveness towards oats and wheat in wounded and unwounded in vitro detached leaf assays. Eur. J. Plant Pathol. 124:117-26. 
Heap I. 2013. International survey of herbicide resistance weeds 2013. Available from: http://www.weedreistence.org

Khoshnevisan B., Rafiee S., Omid M., Mousazadeh H. 2013. Developing an artificial neural networks model for predicting output energy and GHG emission of strawberry production. Int. J. Appl. Operat. Res. 3:43-54.

Kong L., Kadokami K., Wang S., Duong H.T., Chau H.T.C. 2015. Monitoring of 1300 organic micro-pollutants in surface waters from Tianjin, North China. Chemosphere 122:125-30.

Lopp J., Sammul M. 2016. Benefits of clonal propagation: impact of imported assimilates from connected ramets. Plant Ecol. 217:315-29.

Luo J., Zheng Z., Li T., He S. 2018. Changes in micro-relief during different water erosive stages of purple soil under simulated rainfall. Sci. Rep. 8:3483.

Manzone M. 2015a. Energy consumption and $\mathrm{CO}_{2}$ analysis of different types of chippers used in wood biomass plantations. Appl. Energy 156:686-92.

Manzone M. 2015b. Efficiency of a compactor in wood chip volume reduction. Biomass Bioenerg. 80:303-6.

Manzone M. 2016. Energy and $\mathrm{CO}_{2}$ emission associated with mechanical planters used in biomass plantations. Biomass Bioenerg. 87:156-61.

Manzone M., Balsari P. 2014. Planters performances during a very short rotation Coppice planting. Biomass Bioenerg. 67:188-92.

Mikkola H.J., Ahokas J. 2010. Indirect energy input of agricultural machinery in bioenergy production. Renew. Energy 35:23-8.

Miranda-Fuentes A., Marucco P., Gonzalez-Sanchez E.J., Gil E., Grella M., Balsari P. 2018. Developing strategies to reduce spray drift in pneumatic spraying vineyards: Assessment of the parameters affecting droplet size in pneumatic spraying. Sci. Total Environ. 616-7, 805-15.

Miyata E.S. 1980. Determining fixed and operating costs of logging equipment. General Technical Report NC-55. Forest Service North Central Forest Experiment Station, St. Paul, MN. 14 pp.

Narayan S., Liew Z., Bronstein J.M., Ritz B. 2017. Occupational pesticide use and Parkinson's disease in the Parkinson Environment Gene (PEG) study. Environ. Int. 107:266-73.

OIV (International Organisation of Vine and Wine). 2018. Statistical report on world vitiviniculture. International Organisation of Vine and Wine, Paris, France.

Ringselle B., Bertholtz E., Magnuski E., Brandsæter L.O., Mangerud K., Bergkvist G. 2018. Rhizome fragmentation by vertical disks reduces Elymus repens growth and benefits Italian ryegrass-white clover crops. Front. Plant Sci. 8:2243.

Smith K.P. 2013. Water-quality Conditions, and Constituent Loads and Yields in the Cambridge Drinking-water Source Area, Massachusetts, Water Years 2005-07. US Department of the Interior, US Geological Survey, Cambridge.

Tamagnone M., Balsari P., Manzone M., Bozzer C. 2011. Comparison of different spraying equipment used for weed control in vineyards and in orchards. pp 136-138 in $11^{\circ}$ Workshop SuProFruit 2011, 8-10 giugno, Ctifl Lanxade, France.

Uwizeyimana H., Wang M., Chen W. 2017. Evaluation of combined noxious effects of siduron and cadmium on the earthworm Eisenia fetida. Environ Sci. Pollut. Res. 24:5349-59. 